\title{
The Political Morality of School Composition: The Case of Religious Selection
}

\author{
Matthew Clayton ${ }^{1}$, Andrew Mason ${ }^{1}$, Adam Swift ${ }^{2 \star}$ and Ruth Wareham ${ }^{1}$ \\ ${ }^{1}$ University of Warwick and ${ }^{2}$ University College London \\ *Corresponding author. Email: adam.swift@ucl.ac.uk
}

(Received 23 November 2017; revised 26 September 2018; accepted 12 December 2018; first published online 26 June 2019)

\begin{abstract}
This article presents a normative framework for the assessment of education policies and applies it to the issue of schools' selecting their students on the basis of religious criteria. Such policies can be justified, and challenged, on many different grounds; public debate is not conducted in terms adequate to the task. The authors' main objectives are to supplement with non-consequentialist considerations a recent, consequentialist, approach to the normative assessment of education policy proposed by Brighouse et al. (2016, 2018), and to apply the proposed framework to issues of school composition and selection. They argue, further, that policies allowing schools to select all their students on the basis of their parents' religious affiliation cannot be justified.
\end{abstract}

Keywords: education policy; school admissions; religious schools; parents' rights; children's rights

In September 2016 Prime Minister Theresa May announced her government's intention to facilitate the creation in England of new academies with a religious character by abolishing the requirement that they restrict the proportion of pupils selected on the basis of religious criteria to 50 per cent (May 2016). Apparently, this restriction had served as a brake on the creation of new faith academies and free schools: some religious organizations cited it as a reason why they had not been willing to be involved in such a process (Board of Deputies of British Jews 2016; The Catholic Bishops' Conference for England and Wales 2013). This in turn was seen as hindering the government's objective of increasing parental choice and improving educational standards. The evidence showed that the cap on selection according to religion had done nothing to make faith schools more diverse so, it was argued, there was no reason to continue with it (DfE 2016, 31-33).

At the time of writing, the Secretary of State for Education, Damian Hinds, has reneged on the Conservative Party's 2017 manifesto commitment to remove the cap for new academies and free schools but is offering more funding for local authorities to open voluntary-aided faith schools that may admit without a cap (DfE 2018a). That move is entirely in keeping with wider policy developments, such as the shift to academies and free schools itself, which have made it easier for faith-based organizations to enter the education 'market'. The arguments offered for those developments typically combine - or slide between - two claims: on the one hand, parents are entitled to exercise choice over their children's schooling; on the other hand, allowing schools to respond to demand can be expected to improve standards, especially at the bottom. Both considerations are particularly salient in the case of schools with a religious character: parental choice with respect to religion is widely regarded as especially important - more important, say, than choice with respect to schools specializing in science or music - while schools with a religious character are often claimed to be 'better' than their non-religious equivalents.

(C) Cambridge University Press 2019.. This is an Open Access article, distributed under the terms of the Creative Commons Attribution licence (http://creativecommons.org/licenses/by/4.0/), which permits unrestricted re-use, distribution, and reproduction in any medium, provided the original work is properly cited. 
Critics of such policies raise a number of objections. Some appeal to empirical evidence: the better outcomes achieved by such schools are entirely due to the characteristics of the children who attend them. According to these critics, religious schools are not being compared with genuine equivalents, and their better results should be attributed to their composition rather than their religious character (Allen and West 2009; Allen and West 2011; Andrews and Johnes 2016; Dreissen, Agirdag and Merry 2016a; Dreissen, Agirdag and Merry 2016b; ${ }^{1}$ Sullivan et al. 2018). Others raise normative concerns. For some, in so far as religious schools are, for whatever reason, better than the alternatives, it is problematic - objectionably discriminatory - if the benefits of attending such schools are distributed in a way that reflects parents' religious affiliation (Pettinger 2014, 477; Shorten 2017). Others contest the understanding of 'better'. Even where such schools do achieve better test results than genuine equivalents, other pupil outcomes are also relevant to their evaluation. It matters that future citizens acquire not only cognitive skills and knowledge but also tolerant attitudes and dispositions, and the kind of understanding of the lives of others that is best achieved in culturally and religiously diverse 'common' schools (Cantle 2008, 219-221; Gutmann 1996, 164; Kymlicka 2001, 303-5). Still others challenge the deference accorded to parental choice. Children are separate individuals with their own moral standing and interests; they thus have the right to schooling that will both equip them to live autonomous lives and respect their moral independence in the process (Clayton 2006).

The arguments over policy with regard to religious schooling thus invoke a wide range of considerations. Regulation of the curriculum is generally seen as the main way to respect parents' claims to have their children raised in a particular faith while protecting those children from undue influence and producing tolerant citizens who are supportive of liberal democratic norms. But regulation of school admissions also has a part to play: the 50 per cent cap on the proportion of children that a school may select on the basis of religion was introduced to prevent the kind of excessive segregation that is widely regarded as inimical to harmonious relations between different religious and ethnic groups.

This article introduces a clear and coherent analytical framework to identify and assess the heterogeneous normative concerns raised by religious schools, and illustrates its merits by applying it to the regulation of admissions to such schools. The proposed framework applies to questions about religious schooling quite generally. ${ }^{2}$ We concentrate on admissions both because they are currently a focus of policy debate and because there is very little detailed normative discussion of schools' selecting their students on the basis of religious criteria. The issue of selection by academic ability commands a good deal of attention, while familiar debates about elite private schools primarily concern the propriety of selection according to parents' ability to pay. But selection by religion, which raises concerns that include but extend beyond the distributive issues central to those other debates, tends to pass under the radar. Discussion of religious schooling from a normative theoretical perspective has focused far more on curriculum than selection (Gardner 2014; Groothuis 2004; Hand 2003; Hand 2004; Hand 2012; Siegel 2004; Thiessen 1993). We explore what is at stake in policy decisions concerning not what such schools may teach but whom they may teach. ${ }^{3}$

We find that the normative issues are more complex than is commonly recognized. A wide variety of consequentialist considerations are relevant to the assessment of policies that have the intention or effect of influencing the composition of schools, but so too are nonconsequentialist considerations - especially often neglected child-centred ones. ${ }^{4}$ Different considerations pull in different directions, and policy decisions can properly be reached only by

\footnotetext{
${ }^{1}$ Although they note that Islamic schools represent an important exception to this rule.

${ }^{2}$ Indeed, like that proposed by Brighouse et al. $(2016,2018)$, on which it builds, the framework is articulated at such a fundamental level that it can helpfully frame all debates about education policy.

${ }^{3}$ For our views on curriculum, see Clayton et al. (2018).

${ }^{4}$ Our proposal supplements Brighouse et al.'s entirely consequentialist account with non-consequentialist considerations of a kind that they acknowledge (Brighouse et al. 2016, 2018, 27-8) but otherwise ignore.
} 
evaluating their relative importance in particular circumstances. Those decisions also rely on empirical judgements about the likely effects of different policies in the relevant contexts. Our article argues for a clear conclusion: allowing schools to choose all of their students on the basis of religious affiliation cannot be justified on any plausible view about the balance of normative reasons and reading of the empirical evidence. But our main aim is to structure the issues at stake in a way that makes them amenable to systematic and reasoned analysis and discussion. Public debate about these momentous matters is not conducted at a level of sophistication adequate to the task.

The following section clarifies the empirical phenomena under discussion, explaining the nature of school composition effects and their relation to admissions policies. Next we set out the normative considerations at stake; particular attention is paid to non-consequentialist claims neglected by the recent academic literature and taken for granted in public debate. We then apply the proposed framework to the issue of religious selection, defending the claim that religious selection should be capped and suggesting that regulation should aim to achieve religiously mixed compositions.

\section{Selective Admissions and Composition Effects}

We focus on admissions policies, especially schools' use of criteria to select students. Those criteria matter partly because they influence the composition of schools - of both schools that select students and those that do not, or select using other criteria. Any comprehensive assessment of a policy must take into account its impact on all schools that have their composition affected by it.

The significance of admissions policies for school composition should not be overstated. School composition depends on how those policies interact with other circumstances such as residential patterns and parents' choices. Ability to pay or religious affiliation influence school composition wherever spatial proximity plays any role in deciding which children will attend which school, as long as residential patterns are structured by money or religion. A school could be composed entirely of the children of co-religionists without being permitted to use religious selection criteria; it could be allowed to select on that basis yet be substantially composed of pupils from another religious background altogether. Still, selective admissions policies matter partly because they affect the composition of schools; one way they do this is by influencing parents' choices.

But what is the significance of school composition? Why is it important how pupils with different characteristics are grouped together, or combined, in schools? The answer, at its most general, is 'composition effects'. When equated with 'peer group effects', these usually refer to how pupils' academic performance is affected by factors such as the ability, motivation or social class background of others with whom they share a school or classroom. Claims framed in those terms play a major role in debates about the merits and drawbacks of selection by ability, and of streaming or tracking within schools. ${ }^{5}$

For our purposes, however, such effects are better conceived more abstractly as all the ways in which a school's overall composition affects those who attend it. Even if it had no impact on their test or exam results, schools composed entirely of boys, or of pupils who passed an entrance exam, or whose parents were practising Catholics, might be expected to produce students with characteristics different from those they would have possessed if they had attended coeducational schools, comprehensive schools, or schools attended by children from many religious backgrounds. Some of those characteristics might be produced directly by interactions between pupils, so that the 'peer group' played a causal role in the process. But some might result from the effects

\footnotetext{
${ }^{5}$ There is much disagreement about the size, or even the existence, of such effects, mainly due to the difficulty of clearly attributing outcomes to a school's composition when they might result from unmeasured individual pupil characteristics. See, for example, Gorard 2006; Harker and Tymms 2004.
} 
of school composition on other factors, such as how schools are managed and how well they are resourced, as well as curriculum and teaching practices (see Thrupp, Lauder and Robinson 2002).

School composition can affect a wide range of outcomes, and it can affect them through a variety of mechanisms. The mechanisms will differ depending on the dimension of composition (for example, gender, ability, religious background) and the outcome (such as academic results, capacity for healthy personal relationships, understanding of those with a different religious outlook). To count as a composition effect, some properties of the pupils in question must combine to produce the effect, whether more directly (as in peer group effects stricto sensu) or less so. But 'properties of the pupils' should be understood broadly.

Typically, those properties are relevant to the outcomes likely to be achieved by each child as an individual. For example, children's level of ability, motivation or social class background are known to influence at least some of their outcomes, when taken as individuals (Marshall, Swift and Roberts 1997). Here composition effects come into play where there is an independent effect on outcomes resulting from mechanisms produced by combinations of children of particular types: where, for example, a child's outcomes depend not only on her own level of ability or motivation, but also on those of her classmates. But it could be that each individual child's characteristics have no bearing on their educational outcomes; here the composition effect emerges through combinations of children with properties that, taken individually, have no impact on outcomes. For example, it could be that children learn better, or enjoy their childhoods more, when they attend schools with others, or enough others, who are similar to them - with respect to gender, ethnicity or religion, for instance - even though there is nothing about those characteristics that could be expected to affect their educational outcomes or experiences as individuals. Here it is the degree of homogeneity as such that is producing the effect.

Alternatively, it could be that a school's composition affects its ethos, and hence the selfidentity or self-understanding of its pupils - and staff - in ways that affect particular outcomes. It is plausible, for example, that having a high proportion of academically able and highly motivated pupils enables those at a school to think of it as primarily engaged in producing students who achieve good exam results, and that this self-understanding independently contributes to producing those good results. In this scenario, school composition plays a role in so far as it is causally relevant to the maintenance of a particular school ethos and pupil identity, the content of which affects the school's capacity to produce particular outcomes in its pupils. Something similar may apply in the case of schools with a religious character or ethos.

Sometimes 'properties of the pupils' are actually those of their parents. For example, different compositions of parents with different levels or kinds of involvement in their children's schooling may produce their own effects, perhaps by influencing the resources available to a school or affecting its internal policies with respect to homework or extracurricular activities. Parents' characteristics may play a causal role only at the compositional level, and would not similarly affect children's outcomes on an individual basis. For example, J.S. Coleman's (1988, S113) seminal analysis of why Catholic schools in the US perform better, in terms of dropout rates, than both public and other private schools, appeals partly to 'social capital', some of which 'can be found $[. .$.$] in the community consisting of the social relationships that exist among parents,$ in the closure exhibited by this structure of relations, and in the parents' relations with the institutions of the community' (see also Bryk, Lee and Holland 1995). These relations make it easier to enforce informal social norms that are conducive to lower dropout rates. Here the properties are not only those of the pupils by proxy, as it were, with the composition of the school in terms of pupils standing in for a claim about parents, but the relevant properties of the parents are themselves relational rather than inhering in each individual.

Whatever the particular outcomes and mechanisms in question, it is an empirical question what proportion of a school's pupils must have a particular property for that school's composition to produce the specified effects, or rather - since we are surely dealing with scalars here - how much of the effect will be produced by what degree of composition. The answer will presumably 
vary considerably depending on the mechanism, and there is no reason to expect a linear relationship; there may well be tipping points and issues of critical mass. Perhaps most of the beneficial effects that come from parents' being connected through informal social networks kick in as long as 75 per cent of the children have parents with the right kind of ties to others. Perhaps a school can reap whatever benefits result from its capacity to sustain a religious ethos or character with a student body composed 50 per cent of children from families that subscribe to the religious view in question. It may also matter how religious - how devout or orthodox - the families are.

\section{Two Kinds of Normative Considerations}

Arguments for and against selective admissions policies tend to invoke two distinct kinds of consideration. The following subsections consider each in turn.

(1) Consequentialist: selection produces, or fails to produce, various goods or benefits, and/or it distributes those goods or benefits well or badly. Advocates of selection who take this line typically claim (a) that some schools, or all schools (or perhaps some schools in the short run but all schools in the long run) will be better if they select their pupils, and/or (b) that selection improves the distribution of the goods that schools produce. Critics of selection who emphasize consequentialist considerations claim (a) that selection makes schools worse, at least in some respects, and/or (b) that selection worsens the distribution of goods that schools produce.

(2) Non-consequentialist: whether or not it produces (or fails to produce) benefits, or distributes them well or badly, selection respects (or fails to respect) people's rights. Advocates of selection who take this line claim that people are entitled to establish such schools, and that parents or children are entitled to attend them. Critics of selection who emphasize non-consequentialist considerations claim that selection violates the rights of parents or children, or that it is in other ways wrong - albeit not harmful - for schools to select.

\section{Consequentialist}

Arguments that selection makes schools better tend to operate with an implicit view of what it means for one school to be 'better' than another, or than it would otherwise have been. Often the claim is made in terms of the exam results, or test scores, of the kind reported in published league tables. These are presumably (imperfect) indicators of a good thing that we want schools to produce - call it cognitive capacity - which in turn might be valued partly because of its importance for children's labour market prospects. But we might want schools to achieve other goals too. Perhaps, even from a labour market perspective, 'soft skills' are important factors we want schools to develop in children. Perhaps it is also valuable that schools produce children with certain democratic competences or liberal attitudes (such as tolerance). And so on.

A recent attempt to systematize this insight invokes the concept of 'educational goods', conceived as the knowledge, skills, dispositions and attitudes that help people's lives go better as adults and contribute to the quality of other people's lives. It identifies six capacities - for economic productivity, personal autonomy, democratic competence, healthy personal relationships, treating others as equals and personal fulfilment - that one might plausibly want schools to develop in children. ${ }^{6}$ It also lists, among other non-educational values by which schools might be evaluated, 'childhood goods' - such as creativity and play - which are valuable for children irrespective of their developmental benefits (Brighouse et al. 2016; Brighouse et al. 2018).

\footnotetext{
${ }^{6}$ To regard personal autonomy as an educational good is not to deny that there may also be non-consequentialist reasons why it matters that children develop it. Considerations of human dignity, or respect for individual agency, can yield a concern that people are equipped to make autonomous choices even where that is not conducive to wellbeing, whether their own or that of others.
} 
Whatever the merits of that particular specification, claims about what makes schools 'better' (or 'worse') should clearly take into account both the way(s) in which they are better, or the goods they are better at producing, and the possibility of trade-offs between different educational goods: schools that are better with respect to some goods may be worse with respect to others.

But it also matters how those goods, and access to those goods, are distributed. While parents are often concerned only with whether benefits accrue to their own children, policy makers must think about how selection policies are likely to affect both the overall distribution of those benefits and the distribution of opportunities to achieve those benefits. A school might be good at producing high test scores and good citizens, but it might do so by using selection procedures that make it very hard for other schools to do either, or it may achieve those outcomes only as the result of an unfair distribution of opportunities to access the better outcomes. Familiar debates in the literature on educational justice - about educational equality, adequacy, and the idea of prioritizing benefits to the least or less advantaged - play out, in various ways, in arguments about selection (see Brighouse and Swift 2014; Clayton 2018). Perhaps selection, though permitting unequal outcomes, brings immediate benefits to all children; perhaps it benefits some but disadvantages others; or perhaps in the long run it benefits all even though in the short run it leaves some worse off than they might otherwise be. And whatever the distribution of educational outcomes, there are further distributive questions about access to those outcomes. Perhaps, even though a distribution of educational goods could be justified on prioritarian grounds, it could be achieved only by an unfair distribution of the opportunities to access those goods. $^{7}$

Educational goods are unusual in the way that their production and distribution are interconnected. The claim that selection makes schools better involves the idea that a school's composition affects how good it is. But the composition of a school also influences who gets the benefits. In a sense, through these composition effects, the pupils themselves - or at least some characteristics of those pupils (or, as we have seen, of their parents) - help to produce the goods that benefit them. This raises distributive issues in a rather distinctive way. Advocates of selection on consequentialist grounds point to the benefits of selection that, at least in the first instance, accrue to those selected precisely through a mechanism that discriminates against (or excludes) those who are selected out. In standard cases of discrimination, the goods in question are produced independently, as it were, and the issue is only how they should be distributed. In the case of educational goods, production and distribution cannot be treated as wholly distinct processes.

This means that there may be trade-offs between (a) the total amount of educational goods, (b) the proper distribution of the goods and (c) the fair distribution of access to places in that distribution. If selective schools are better because of their composition, and that composition is achieved by discriminating against particular types of pupils, then we might think that the latter are denied fair access to the benefits. Since, however, those benefits only arise, ex hypothesi, because of the selection process, and the benefits are in a sense produced by those who receive them, the normative issues raised by the trade-off differ from standard efficiency vs. equity or quality vs. equality cases.

So far we have assumed that (i) the benefits of educational goods accrue entirely to those who possess them and (ii) the goods produced by schools should be understood entirely as 'educational goods'. Neither assumption is valid: the benefits that result from educational goods can accrue to people other than the educated person, and those benefits need not themselves be understood as consisting of educational goods. On (i), consider, for example, the benefits achieved from educating children to be democratically competent, or to relate to one another as equals. Here the good consequences that follow from educating children in these ways accrue

\footnotetext{
${ }^{7}$ Brighouse et al. $(2016,2018)$ neglect the distinction between (i) the distribution of educational goods and (ii) the distribution of opportunities to access to those goods.
} 
at least partly to those with whom the children do, or will, interact. There are, we might say, positive externalities or 'spillovers' that arise from the goods in question. On (ii), the benefits in question are not themselves 'educational goods', or at least not exclusively so. Rather, they are the goods that come from living in a polity where one's fellow citizens are democratically competent, or in which they regard one another as equals.

Evaluating school selection and admissions policies from a consequentialist perspective requires keeping in mind both the full range of benefits produced by educational goods and the fact that those benefits need not accrue entirely to the people who possess the educational goods themselves. This complicates the significance of the distinctive interdependence between the production and distribution of educational goods. Composition effects mean that, to some extent, those who receive such goods are also the ones who produce them; it is peculiarly difficult to disentangle their production and distribution. But the benefits produced by educational goods may be enjoyed by people other than those who receive those goods, and the benefits may be enjoyed in a different metric. Suppose, for example, that introducing selection increased some children's level of some or all educational goods but decreased the level of some or all of the educational goods received by other children. We cannot assess the full distributive impact of selection without knowing the effect on all relevant measures of advantage. Perhaps, for example, an increase in cognitive skills enjoyed by those selected will result in scientific advances that benefit, in other ways, those who suffer the loss with respect to educational goods. Or perhaps the greater productivity of those who are advantaged with respect to educational goods can be channelled, via redistributive policies, to those who are less productive. The extent to which educational goods enjoyed by some affect the advantage of others depends in large part on policy in other areas. Policy decisions concerning selective school admissions and education policy should be approached in an integrated or holistic fashion, in light of the interactions between education and other policy areas. ${ }^{8}$

To summarize, the consequentialist approach evaluates admissions policies by considering the benefits or goods that they are claimed to produce, and how those benefits or goods are distributed. Selection may make some - or all - schools better at producing some of those goods but worse at producing others; there may also be trade-offs between the value of producing more goods, educational or otherwise, and the values both of distributing them well and of distributing access to them fairly.

\section{Non-consequentialist}

In addition to addressing questions about educational goods and their distribution, debates about admissions policies might reflect non-consequentialist considerations. Identifying the right tradeoff between different educational goods, and what justice demands with respect to their distribution and access to them, might not settle the question of what policy makers ought to do.

We understand non-consequentialist reasons as reasons that tell against acting in ways that promote good outcomes, or that permit individuals to act in ways that fail to promote them. These are often expressed in the language of rights, though it is important to note that some claims expressed in such terms appeal to consequentialist considerations. If a right is justified solely on the grounds that its violation would harm the rightholder, or fail to respect a rightgrounding interest, then the right is consequentialist in character. Non-consequentialist rights, by contrast, pick out reasons for acting that have force independent of the promotion of good outcomes.

First, individuals or groups might have rights that protect them from certain kinds of treatment. Such rights limit how good outcomes can permissibly be produced. For example, suppose we agree that the elimination of world poverty is part of the best outcome overall. Still, many

\footnotetext{
${ }^{8}$ For examples of integrated or holistic analyses, see Dworkin (2002) on health care and Caney (2012) on climate policy.
} 
believe that individuals have rights over their own property such that others may not steal from them even in order to advance that laudable end. Similarly, in the context of schooling many object to admissions policies that realize valuable composition effects by legally requiring particular children to attend certain schools. One way of elaborating this non-consequentialist thought appeals to the means principle, according to which it is sometimes morally wrong to use others to advance good outcomes. A child who is legally required to attend a particular school because her inclusion in it would be optimal in terms of producing educational goods and their fair distribution might object that such a policy treats her as a means for the benefit of others rather than as an end in herself.

Secondly, some non-consequentialists insist that individuals or groups have the moral option to engage in activities that fail to produce the best outcome overall (Kagan 1989). For example, groups of like-minded people may have the right to set up schools that select pupils on the basis of particular characteristics such as sex, religion or sporting ability. Some hold that they have that right even if allowing the proposed schools would produce worse outcomes than could be achieved by different admissions policies.

Before going into more detail, notice how the distinction between consequentialist and nonconsequentialist considerations can clarify the claim that parents have the right to choose their children's school. Sometimes parental choice is defended in consequentialist terms, as a mechanism for improving educational outcomes. It is often claimed, for example, that parental choice generates incentives for schools to improve the teaching and learning they provide, which raises educational standards generally. However, a policy of parental choice might also, or instead, be motivated by non-consequentialist concerns. At least within some acceptable range, parents might be morally permitted to choose the school their children attend, even if denying them choice and allocating school places in other ways would produce better outcomes - including better distributive outcomes.

Non-consequentialists tend to endorse free association. Individuals who share particular religious, aesthetic or sporting interests are morally permitted to co-operate to pursue their commitments and to exclude those who do not share their goals from the association. Furthermore, the community should protect associative freedom, provided that the group is not motivated by racist or other wrongful discriminatory attitudes. In the central cases of freedom of association, what is protected is association between consenting adults. Schooling raises more difficult issues because it involves some (adults) deciding how others (children) are educated. Non-consequentialists disagree about the implications of their view for school policy, because they hold different views about who are the bearers of the rights in question.

According to parent-focused non-consequentialism, parents have a moral claim to choose which school their child attends. Some defend this right as a part of parents' entitlement to pursue their own conception of the good (Fried 1976; Galston 2002). On this view, a religious or other group has the right to set up a school and to decide its admissions policies on the basis of the group's values. Once the mix of schools has been settled by different groups exercising their freedom of association, parents have the right to choose the school their children attend from the set of schools willing to admit them. A group might see educating the children of its members as part of its mission and refuse to admit children of non-members; a group might want to teach only girls or boys, or less or more able children, or children of parents with a particular religious affiliation, and so on. To the extent that freedom of association is taken seriously, groups ought to enjoy freedom over their schools' admissions criteria, and parents ought to enjoy the right to apply to any school and for their applications to be judged according to the school's particular admissions code.

As presented, this view avoids certain objections. For example, suppose that a particular group wants to set up a grammar school that creams off a large percentage of able pupils from surrounding schools. Does the grammar school violate the rights of parents who want their less able child educated in a comprehensive school? Not according to the non-consequentialist 
considerations as we have described them. To enjoy that right it would have to be morally permissible for those parents to constrain others' choices in order to fulfil their own preferences for their child's education. However, we lack a moral permission to constrain others in that way. Parents are free to choose only among those schools available given the choices of educational providers and consumers. The right to choose is not the right to choose how others choose.

According to child-focused non-consequentialism, the bearers of non-consequentialist rights in education are children, not parents, so parents' freedom to choose their children's school is limited. ${ }^{9}$ Various versions are available, depending on the particular rights ascribed to children. On one version of this view, it is morally wrong for anyone - parents as well as the political community - to force children to become part of an association by sending them to schools that obstruct the development of their capacity for personal autonomy. Another version contends that children's rights are violated whenever they are directed towards controversial religious belief systems. ${ }^{10}$ The particular worry here concerns adults intentionally enrolling their children into controversial conceptions of the good, such as particular religious doctrines. Plainly, parents and adults act in countless ways that affect the beliefs, desires and prospects of children. However, many in the non-consequentialist tradition argue that, while it is often morally permissible to affect others as a side effect of one's conduct, it is often morally wrong to make others perform acts that they are not morally required to perform or to impose harms on them they are not morally required to incur (Tadros 2015). Non-consequentialist arguments for parental choice assume that parents have a moral right to determine (at least provisionally) the religious or occupational ends that their child pursues; but if everyone has a right to set her own ends, then parents do not enjoy that right over their children (Clayton 2006). According to child-focused non-consequentialism, then, it is not fundamentally objectionable for a government to deny parents the opportunity to send their child to a school that is run in accordance with their religious convictions.

Child-focused non-consequentialists object to certain kinds of schooling. For adherents of this view, even if it is permissible for individuals who pursue particular religious or ethical goals to associate together to jointly realize their shared ends, they may not impose those ends on children. For that reason, it would be wrong for a school to operate an admissions policy that seeks to include some and exclude others in order to achieve a pupil composition that facilitates the realization of a controversial ethical view. But this does not rule out as morally impermissible all attempts to frame admissions policy to generate composition effects. For example, the right of children to set their own religious ends rather than have them imposed on them by others does not condemn others' making children learn norms of civility and toleration. It does not violate the child's rights if she is made to attend a particular school because her going there makes it more likely that pupils in that school learn various civic virtues. Such a policy is not rights-violating if the children themselves have a moral duty to contribute to the production of such virtues. True, an admissions policy geared towards selecting a particular profile of pupils to further the virtue of tolerance, for example, uses the child to produce a good outcome. But it might not wrong the child if it uses her to realize a good that she has a duty to bring about.

Non-consequentialist considerations complicate the moral picture with respect to school admissions and school choice. The core idea is that a policy might wrong people even if it is effective at producing schools with pupil compositions that lead to better outcomes with regard

\footnotetext{
${ }^{9}$ Child-focused non-consequentialists might endorse parents' being granted some legal rights with respect to their children's education on the grounds that parents are best placed or best motivated to act in ways consonant with their children's fundamental moral rights. Even if one denied that parents had any moral rights with respect to their children's upbringing, and saw their role as entirely fiduciary, one might still support a system of devolved authority that gave parents legal rights within certain limits.

${ }^{10}$ Other versions are possible. For example, it might be that children have a claim to have their views about their schooling listened to or, sometimes, to have their views determine how they are educated. For views of this kind, see Bou-Habib and Olsaretti 2015; Mullin 2014.
} 
to the production and distribution of educational goods. How that idea plays out in detail, and how radical a revision of educational policy it calls for, turns on the answer to further questions, such as whether non-consequentialist rights primarily protect children or their parents, and how exactly the rights in question are understood.

\section{Combining Considerations}

We have reviewed two kinds of reason relevant to questions about school admissions: consequentialist considerations that include the production and distribution of educational goods as well as other goals that an education policy might serve, and non-consequentialist considerations that might be elaborated in terms of a commitment to respect the rights of parents and/or children. A justified education policy must identify not only which of the considerations are valid but also the right way to combine them if several are in play.

There are two general ways of approaching this task. First, one might think of each of the different reasons as having pro tanto force: one identifies the policy (for instance, a particular admissions policy) that a particular reason (such as a particular educational good) supports but then considers whether there are other competing reasons (for example, other educational goods, non-educational goods or non-consequentialist considerations) that outweigh the initial reason and favour a different educational policy. According to this trade-off view, all relevant reasons are weighed in the balance. Policy makers must identify how important or weighty those different reasons are and judge which policy is best, all things considered. Note here that nonconsequentialist rights can be understood as reflecting respect for individuals' claims or agency without regarding them as absolute constraints that always defeat consequentialist considerations. Such rights can have merely pro tanto, rather than always trumping, force, so they can be outweighed if the good that is produced as a result is sufficiently important.

One problem with the trade-off view is that it is sometimes hard to see how it produces determinate policy prescriptions, because it does not deliver clear rules to guide decision making (Rawls 1971). So some propose a second way of combining considerations - one that involves rules that prioritize some considerations over others. On this view, certain considerations may become relevant only when others have been satisfied. For example, it is plausible that an educational minimum should be guaranteed for all: whatever other consequentialist or non-consequentialist reasons are in play, a view is implausible if it fails to deliver an adequate education, understood as a reasonable opportunity for every child to acquire capacities for participation in the labour market, personal autonomy, democratic competence, healthy personal relationships and treating others as equals.

\section{Applying the Framework: Regulating Religious Selection}

We now apply our framework to consider the regulation of schools' use of religious criteria to choose their students. The government caps the proportion of pupils that new academies and free schools can select on the basis of religion at 50 per cent, but there are still many schools that are allowed to choose all their pupils on that basis, and the government has recently encouraged an expansion of the number of places in such schools. If everybody benefitted from the provision of schools composed entirely of children of co-religionists, or at least if that admissions regime satisfied appropriate distributive desiderata, and if no non-consequentialist considerations were disregarded in the process, then those schools would pose no normative problems. We will see, however, that different considerations pull in different directions. One has to construe educational goods very narrowly to believe that permitting schools to select entirely religiously homogeneous compositions is a good way of producing them, and even so the claim is doubtful. Since, moreover, a 'no cap' policy both raises distributive concerns and threatens child-focused nonconsequentialist rights, we believe that policy to be unjustified, all things considered. To find 
in its favour, one would have to endorse an implausible view of parents' non-consequentialist rights and of their importance relative to other competing considerations.

Does that mean that we are defending the 50 per cent cap? Here we must remind readers of the specificity and modesty of our argument. Our main aim has been to present a coherent framework for analyzing the normative issues raised by religious selection. Any determinate conclusion about the regulations that should apply to admissions policies will combine a variety of judgements - some normative, some empirical. On the normative side, there is scope for reasonable disagreement about the significance and relative importance of the different educational goods, distributive principles and non-consequentialist considerations that we have identified. Although each of us might be willing to defend our own particular view, that would take more space than is available, we would doubtless disagree, and in any case such an attempt would only distract from our purpose. On the empirical side, we simply lack the expertise to offer an informed determinate view about the admissions regime most likely to produce and respect any particular combination of goods and values. While confident that capping at some level can be justified, we hold no brief for 50 per cent rather than, say, 30 per cent.

\section{Producing Educational Goods}

Part of the government's rationale for encouraging religious organizations to open new schools has been that such schools tend to perform well (DfE 2016, 30). They can thus play an important role in providing not merely the 'more school places' demanded by demographic change, ${ }^{11}$ but the 'more good school places' (our italics) that the government seeks to offer (DfE 2016, 5, 9). The implicit suggestion here is that schools' religious character plays a distinct causal role in explaining their good performance. As far as composition and admissions are concerned, the assumption is that bringing together children from homes that share a religious outlook makes it possible to sustain an ethos or shared culture, ${ }^{12}$ or perhaps simply for parents to informally enforce relevant norms, in ways that are conducive to better educational outcomes, perhaps especially through effects on discipline and behaviour. But there has been considerable debate about whether the schools in question are as 'good' as they seem, about the role that religious selection plays in generating such goods as they do achieve, and about whether, even if it were granted that they are particularly productive of some educational goods, they are problematically unproductive of others.

Those who doubt that religious schools tend to perform particularly well point to their composition, and suggest that their 'good' headline results, as measured by test scores and exam results, are a function not of their religious character but of their pupils' characteristics. Once one controls for other variables known to predict student performance, such as the proportion of children eligible for free school meals, religious schools perform no better than others (Andrews and Johnes 2016; Dreissen, Agirdag and Merry 2016a; Gibbons and Silva 2011; Sullivan et al. 2018). Their religious character may perhaps play a role in determining which pupils attend them, though even here there is evidence that many parents choose such schools because they are perceived to be 'good schools' rather than for religious reasons. ${ }^{13}$ But in any case, their better results are not produced by their religious composition.

\footnotetext{
${ }^{11}$ Current projections indicate there will be a 14.7 per cent increase in the number of secondary school age pupils between 2018 and 2027. This amounts to 418,000 additional school places (DfE 2018b, 3).

${ }^{12}$ Much of the literature expressing or examining this view concerns Catholic schools. See, for example, Donlevy 2009; Mulligan 1999, 182.

${ }^{13} \mathrm{~A}$ recent poll (YouGov/University of Lancaster 2013) suggested that academic standards, location and discipline are far more likely to influence school choice than religious character. See also Butler and Hamnett 2012. Many readers in the United Kingdom will be familiar with the phenomenon (explored comically in the BBC series Rev) whereby parents mysteriously (re) discover their faith and resume church attendance as school admissions decisions loom.
} 
Wherever the truth lies in those disputes, the more familiar objection to religious selection is that, however good they may be in terms of their students' test scores and exam results, schools that educate only - or too disproportionately - children from a particular religious background are less likely to cultivate other educational goods. Some focus on the kind of tolerant civic attitudes and dispositions that are needed in a well-functioning liberal democracy. Those attitudes and dispositions - which should also be regarded as 'educational goods' - are best fostered in contexts where children of different faiths come into contact with one another on a daily basis (Allport 1954; Dhont, Hiel and Hewstone 2014; Hewstone et al. 2018; Hughes et al. 2013). To the extent that schools foster this kind of educational good, they are providing benefits not only to their pupils, but also to the wider society. ${ }^{14}$

The worry that religious schools hinder the production of civic goods can be traced back at least as far as the Cantle Report on the 'disturbances' in a number of northern towns in 2001. It argued that faith schools pose a particular threat because they tend to segregate children by religion, and so should offer 25 per cent of their places to children from families of a different faith or denomination (HMSO 2001, 37). Resistance from the Catholic Church and the Board of Deputies of British Jews helped to prevent the adoption of that proposal, but a similar concern seems partly to have motivated the 50 per cent cap on religious selection in new free schools and academies.

Others worry less about the civic benefits of religiously mixed schools than the impact on the educational good of personal autonomy. Perhaps regulating the curriculum is not enough to ensure that children develop the capacity to make independent judgements about how to live their lives. In order for them to form their own informed opinions about religious and other questions, and to properly appreciate the range of options available to them, it is important that children from different religious backgrounds interact with and get to know each other in a school environment.

If schools' admissions policies were designed solely to produce educational goods, it would be important to assess their impact on the school system as a whole, not only on those to whom the rule applied. Religiously selective schools might achieve a high level of educational goods by mechanisms - like admitting disproportionately few students who are hard to teach - that make it harder for other schools to perform well. If some schools' success comes at the expense of others, then a concern for the production of educational goods alone might point towards a different policy. In any case, different policies would presumably tend to produce different goods in different combinations, so policy makers would have to form a view about the optimal balance. That view, like the effect of admissions policies on production itself, would doubtless be context dependent. In some circumstances, particular weight might be given to the goods of trust, tolerance and mutual respect; in other circumstances, there might be less need to trade off other educational goods for their sake. Having decided on the optimal balance, the next step would be to judge what admissions policies were most conducive to that end. What degree or kind of religious diversity does a school need in order to foster virtues such as tolerance and mutual respect? What proportion of pupils at a faith school need to be from families that share its faith for it to sustain a religious ethos, or to possess whatever other properties make it academically successful ${ }^{15}$ We offer no precise judgements on the normative question of the optimal balance of goods, and we cannot answer the empirical questions. But we see no reason to think that allowing schools to choose all their students on the basis of religion is the right way to go.

\footnotetext{
${ }^{14}$ In England this concern is usually discussed in terms of the rather vague concept of 'community cohesion'. See DCSF (subsequently renamed DfE) (2007) and, for a critical discussion, Mason (2010).

${ }^{15}$ Brighouse $(2009,90)$ 'imagines' that 30 per cent constitutes the critical mass for a school to maintain its faith character. Church of England officials appear increasingly convinced that since a distinctively Christian ethos is about 'serving the common good', it can usually be sustained without admissions policies intended to influence school composition at all (see Church of England Education Office 2016).
} 


\section{Distributing Educational Goods}

As well as affecting the level and mixture of educational goods produced, admissions policies also influence their distribution. Some defend religiously selective schools on the grounds that they are particularly good at serving less advantaged children. ${ }^{16}$ We take this justification of religious selection to appeal to considerations that are egalitarian (if the aim is to reduce gaps between children from different backgrounds) or prioritarian (if it is simply to raise the bottom of the distribution). Others object by invoking different distributive ideals, such as fair access to advantage. Why should children whose parents espouse a particular religious view have preferential access to 'better' schools? Even if the religious character of such schools does play a genuine causal role, and the achievements of its pupils are not merely a spurious result of other factors, it is questionable whether children's chances of achieving less or more educational goods may properly depend on their parents' religious inclinations.

Bringing distributive issues into the picture suggests another rationale for capping religious selection. Consequentialist considerations taken together might involve policy makers in compromises between productive and distributive concerns. The aim would be to achieve school compositions that strike the best balance between producing more, and the right mix of, educational goods, on the one hand, and distributing access to them fairly, on the other. From this perspective, a cap of, say, 50 per cent would not simply represent a judgement about the proportion of their intake that religious schools should be allowed to select on religious criteria in order for the system as a whole to achieve a good level and mix of educational goods. It would also reflect the view that the beneficial effects of composition should not be monopolized by members of a particular religious group but instead be shared with the wider local community. Rather than appealing simply to productive considerations, as it were, such as the fostering of 'community cohesion', an admissions rule might also be an attempt to address a concern about the fair distribution of access to educational goods. Although, again, the precise level of the cap depends on complex balancing and empirical judgements beyond our purpose and capacity, factoring in distributive concerns makes a 'no cap' policy even less defensible, on consequentialist grounds, than focusing on production alone.

\section{Non-consequentialist Considerations}

Much debate about religious selection turns on views about parents' or children's rights. Sometimes those rights are - or are derived from - claims about educational goods. As we noted, some justifications for parents being given the right to choose their children's schools appeal to empirical claims about the effects of that freedom of choice on school quality. And since the capacity for autonomy is an educational good, the concern that children have a right to the kind of schooling that will facilitate the development of that capacity can count, for us, as a consequentialist consideration. But some claims about rights are not like this. Irrespective of the consequences, some argue, parents have a right to have their children educated in schools with a religious character that can only be sustained by a particular composition, and hence by particular admissions policies. Others object to religious schools, and religious selection, by appealing to children's right to a school environment that will foster their capacity for autonomy, which matters for non-consequentialist reasons, or their right not to be subject to parents' decisions of that kind.

The basis and scope of parents' rights with respect to their children's schooling is a topic of lively dispute in the philosophical literature, but that controversy is almost entirely absent from policy discussions. Such debates usually assume that parents have the right to raise their

\footnotetext{
${ }^{16}$ For the Muslim case, see Dreissen, Agirdag and Merry (2016a). The evidence for Catholic schools is highly disputed, a lot turning on the baseline against which one assesses the social composition of any particular school; see Allen and West (Allen and West 2009; Allen and West 2011), CES (2017, 48), Fair Admissions Campaign (2014), Pring (2018, 41-44).
} 
children as members of a particular religion, and that this extends to sending them to schools that seek to inculcate a particular religious view. ${ }^{17}$ If parents have the right to send their children to schools with properties that require particular kinds of composition, and hence certain admissions policies, then those policies are justified by appeal to parents' rights. A crucial question then concerns what kinds of admissions policies are required for a school to sustain the properties in question. Here we face the same issues as those discussed above, but this time they arise out of a non-consequentialist concern to respect parents' rights, rather than a consequentialist concern with the production or distribution of educational goods.

Where parent-focused non-consequentialist claims tend to be taken for granted in public debate, child-focused ones are notable for their absence. Some faith schools aim to shape the beliefs and values of their pupils in order to foster religious commitment. It may be that they do not aim to close the minds of their pupils: they might intend to cultivate in them the capacities required for critical reflection while at the same time nudging them towards the beliefs and values that are central to the school's religious character. If successful, this would be consistent with views that suppose that respect for the child's independence is achieved by cultivating a capacity for personal autonomy (MacMullen 2007; McLaughlin 2008). But it will run counter to more demanding conceptions which suppose that, irrespective of any benefits or disadvantages that children might thereby enjoy or suffer, enrolling them in a comprehensive moral doctrine treats them as a mere means and violates their independence (Clayton 2006).

We do not provide a comprehensive assessment of these competing non-consequentialist claims. Nor do we propose a complete account of how they should be combined with judgements about the production and proper distribution of educational goods to yield fine-grained conclusions about admissions policies. Still, nothing here, when joined with the consequentialist considerations outlined above, could plausibly ground a 'no cap' policy. Such a policy would be justified only if parents' right to decide about their children's schooling were part of, or akin to, their own right to freedom of religion or association, rather than a right exercised over another, and even then it would have to be weighty enough to trump all competing considerations. Taken together, children's capacity for autonomy, some threshold level of civic goods and more general distributive concerns, at least of a sufficientarian kind, are surely too important for that position to be sustained.

To reject this view is not to deny that parents' non-consequentialist rights might have priority of a more constrained nature, within a certain range of outcomes. Perhaps, for example, parents should indeed be free to choose their children's schools as long as children's basic interests including their interest in autonomy - are satisfied, and as long as civic goods are produced to some minimal extent. Also on the table are child-centred non-consequentialist positions that recognize reasons to care about civic goods and distributive considerations. As we noted above, plausible views of this kind are consistent with those concerns because it is permissible to use children to achieve outcomes that they have a duty to bring about. And nothing we have said rules out entirely consequentialist views focused on children's interests and civic concerns. Properly defending a determinate view on religious selection by schools requires both taking a stand on these normative questions and supporting that view with relevant empirical evidence.

\section{Conclusion}

Political debates concerning elite private education and academic selection are conducted in terms that show at least some awareness of the range of relevant normative considerations. Our proposed analytical framework should help clarify the competing claims in those debates,

\footnotetext{
${ }^{17} \mathrm{~A}$ more modest view, which we find more plausible, is that the right extends only to having one's child attend a school with a particular religious ethos or character; 'instruction', in school, in a particular faith is a different matter. See Clarke and Woodhead (2015) and Clayton et al. (2018).
} 
but our main aim has been to deepen the relatively limited and superficial appreciation of what is at stake, normatively speaking, in admissions policies that allow schools to select their students on the basis of religious criteria. Such policies can be justified, and challenged, on many different grounds. If nothing else, we trust that we have at least established that identifying and balancing the various relevant considerations is a complex task.

It would be easier if all good things went together. In her speech proposing to drop the cap on religious selection, Prime Minister Theresa May seemed to suggest that they do:

Britain has a long history of faith schools delivering outstanding education. They already account for around a third of all mainstream schools in England. They are popular with parents and significantly more likely than other schools to be rated by Ofsted as good or outstanding [...] I believe it is wrong to deny families the opportunity to send their children to a school that reflects their religious values if that's what they choose. And it's right to encourage faith communities - especially those with a proven record of success, like the Catholics ${ }^{18}$ - to play their full part in building the capacity of our schools (May 2016).

Unfortunately, the normative issues - what counts as 'success'? what are the implications for others, or for the children themselves, of allowing 'families' (that is, parents) to choose a religious school for their child? - are not as amenable as she thinks.

We conclude with three more general observations. First, in so far as admissions policies aim to achieve schools with particular compositions, and whether those compositions are wanted for productive, distributive or non-consequentialist reasons, it is hard to see why policy should not seek to influence them more directly, for example by incentivizing schools to achieve the desired proportions of students with different properties. As we emphasized, admissions policies and school compositions are different - and in many respects it is the latter that matter. But if it is indeed school composition that plays the causal role, then policy should aim to influence it more directly. It might, as Cantle recommended, require that faith schools offer some proportion of their places to children of other faiths or denominations. Or it might require a weighted lottery with weightings aimed at achieving 'better' compositions. Or schools might be given incentives to achieve those compositions, such as a 'religious diversity premium' analogous to the pupil premium currently attached to children from disadvantaged backgrounds (Clayton et al. 2018, 36). ${ }^{19}$

Secondly, if we are right that the 'no cap' policy is misguided - and with respect to new free schools and academies the government now seems to agree with us - it is hard to see the case for allowing existing schools, or new voluntary-aided faith schools, to continue to operate it. The legitimate expectations of the former may suggest a long slow process of phasing out such arrangements rather than sudden drastic change. But the aim of producing students with good levels - and the right mix - of knowledge, skills, attitudes and dispositions surely applies across the board, as does the importance of appropriately respecting the relevant non-consequentialist

\footnotetext{
${ }^{18}$ The proposal to drop the cap was, in part, a response to the Catholic Education Service's (CES) refusal to create any new Catholic academies while it remained in place. The CES objected that it would be against Canon Law for a Catholic school to observe the cap, since doing so might require it to reject a child simply on the grounds of her (or her parents') Catholicism (The Catholic Bishops' Conference for England and Wales 2013; Catholic Education Service 2016). Both elements of this claim are moot. On the former, the Second Vatican Council's Declaration on Christian Education (Gravissimum Educationis) states that the function of Catholic schools involves ' $[. .$.$] caring for the needs of those who are poor in the$ goods of this world or who are deprived of the assistance and affection of a family or who are strangers to the gift of Faith' (Vatican Council II 1965). What is more, many Catholic schools in the private sector, and in other countries, do not engage in religious selection (indeed, religious selection is prohibited in public schools in the majority of OECD countries (see Musset 2012, 15)). On the latter, the cap seems to permit the remaining places to be filled on the basis of faith-neutral considerations (such as proximity to the school), so it is not clear that schools would ever be required to reject applicants solely on the grounds of their Catholicism.

${ }^{19}$ Compare Brighouse's (2000, 184-185) discussion of similar proposals aimed at creating schools composed of children from different social class backgrounds.
} 
considerations. In our view, current policy is best understood not as normatively robust but as bowing to pressures and demands that are given particular force by the British government's heavy reliance on religious organizations to educate the country's children.

Finally, and in similar vein, although we have focused our policy discussion on state schools, our analysis is no less applicable to the independent sector. It is widely thought that the government has less business regulating parents who educate their children at their own expense than those who send them to state schools, but our framework is intended to map all the relevant normative terrain. Human rights law may indeed protect from state interference parents' freedom to choose the kind of religious education their children receive, including their freedom to choose schools composed entirely of the children of co-religionists, in effect treating such decisions as 'private' (Taylor 2015). For us, that is because the law in question enshrines a nonconsequentialist parent-focused right that should be rejected as normatively indefensible.

Author ORCIDs. (D) Adam Swift, 0000-0003-4116-176X.

Acknowledgements. We are grateful to the Spencer Foundation (Major Grant 201500102) for their generous support both for this article and for the project that spawned it: Faith Schools: Principles and Policies. We thank Paul Bou-Habib and four anonymous referees for helpful comments that did much to improve the article.

\section{References}

Allen R and West A (2009) Religious schools in London: school admissions, religious composition and selectivity. Oxford Review of Education 35 (4), 471-494.

Allen R and West A (2011) Why do faith secondary schools have advantaged intakes? The relative importance of neighbourhood characteristics, social background and religious identification amongst parents. British Educational Research Journal 37 (4), 691-712.

Allport G W (1954) The Nature of Prejudice. Cambridge, MA: Addison-Wesley.

Andrews J and Johnes R (2016) Faith Schools, Pupil Performance and Social Selection. London: Education Policy Institute.

Board of Deputies of British Jews (2016) Board of Deputies writes to education secretary over faith school admission procedure. Available from https://www.bod.org.uk/board-writes-to-education-secretary-over-faith-school-admission-procedure/, accessed 20 September 2018.

Bou-Habib P and Olsaretti S (2015) Autonomy and children's well-being. In Baggatini A and Macleod C (eds), The Nature of Children's Well-Being: Theory and Practice. Dordrecht: Springer, pp. 15-33.

Brighouse H (2000) School Choice and Social Justice. New York: Oxford University Press.

Brighouse H (2009) Faith schools, personal autonomy and democratic competence. In Haydon G (ed.), Faith in Education: A Tribute to Terence McLaughlin. London: Institute of Education, pp. 78-93.

Brighouse $\mathbf{H}$ et al. (2016) Educational goods and values: a framework for decision-makers. Theory and Research in Education 14 (1), 3-25.

Brighouse H et al. (2018) Educational Goods: Values, Evidence and Decision Making. Chicago, IL: Chicago University Press.

Brighouse H and Swift A (2014) The place of educational equality in educational justice. In Meyer K (ed.), Education, Justice and the Human Good. Abingdon, Oxon: Routledge, pp. 14-33.

Bryk AS, Lee VE and Holland PB (1995) Catholic Schools and the Common Good. Cambridge, MA: Harvard University Press.

Butler T and Hamnett C (2012) Praying for success? Faith schools and school choice in East London. Geoforum 43, $1242-$ 1253.

Caney S (2012) Just Emissions. Philosophy and Public Affairs 40, 255-300.

Cantle T (2008) Community Cohesion. A New Framework for Race and Diversity. Basingstoke: Palgrave Macmillan.

The Catholic Bishops' Conference for England and Wales (2013) Statement: Admissions to Catholic Schools. Available from http://www.catholic-ew.org.uk/Home/News/2013/School-Admissions (accessed 20 September 2018).

Catholic Education Service (CES) (2016) Catholic Church welcomes prime minister's removal of the cap on faith admissions. Press Statement - 9th September 2016. Available from http://www.catholiceducation.org.uk/component/k2/item/ 1003609-catholic-church-welcomes-prime-minister-s-removal-of-the-cap-on-faith-admissions (accessed 20 September 2018).

Catholic Education Service (CES) (2017) Catholic Education Service Digest of 2017 Census Data for Schools and Colleges in England. Available from http://www.catholiceducation.org.uk/images/CensusDigestEngland2017.pdf (accessed 20 September 2018). 
Church of England Education Office (2016) Church of England Vision for Education Deeply Christian, Serving the Common Good. Available from https://www.churchofengland.org/more/education-and-schools/vision-education (accessed 20 September 2018).

Clarke C and Woodhead L (2015) A New Settlement: Religion and Belief in Schools. London: Westminster Faith Debates. Clayton M (2006) Justice and Legitimacy in Upbringing, Oxford: Oxford University Press.

Clayton M (2018) Education. In Olsaretti S (ed.), The Oxford Handbook of Distributive Justice. Oxford: Oxford University Press.

Clayton M et al. (2018) How To Regulate Faith Schools. Philosophy of Education Society of Great Britain IMPACT series. Oxford: Wiley.

Coleman JS (1988) Social capital in the creation of human capital. American Journal of Sociology 94, S95-S120.

Department for Children, Schools and Families (DCSF) (2007) Guidance on the duty to promote community cohesion. Available from http://www.tedcantle.co.uk/publications/029\%20Guidance\%20on\%20duty\%20to\%20promote\%20community \%20cohesion\%20in\%20school.pdf (accessed 20 September 2018).

Department for Education (DfE) (2016) Schools that Work for Everyone. Available from https://consult.education.gov.uk/ school-frameworks/schools-that-work-for-everyone/ (accessed 20 September 2018).

Department for Education (DfE) (2018a) Drive to create more good school places for families: May 2018. Available from https://www.gov.uk/government/news/drive-to-create-more-good-school-places-for-families (accessed 18 September 2018

Department for Education (DfE) (2018b) National pupil projections - future trends in pupil numbers: July 2018. Available from https://www.gov.uk/government/statistics/national-pupil-projections-july-2018 (accessed 18 September 2018).

Dhont K, Hiel AV and Hewstone M (2014) Changing the ideological roots of prejudice: longitudinal effects of ethnic intergroup contact on social dominance orientation. Group Processes \& Intergroup Relations 17 (1), 27-44.

Donlevy JK (2009) Catholic school administrators and the inclusion of non-Catholic students. Journal of Educational Administration 47 (5), 586-608.

Dreissen G, Agirdag O and Merry MS (2016a) The gross and net effects of primary school denomination on pupil performance. Educational Review 68 (4), 466-480.

Dreissen G, Agirdag O and Merry MS (2016b) The Catholic school advantage and common school effect examined: a comparison between Muslim immigrant and native pupils in Flanders. School Effectiveness and School Improvement 28 (1), 123-135.

Dworkin R (2002) Justice in the distribution of health care. In Clayton M and Williams A (eds), The Ideal of Equality. Basingstoke: Palgrave Macmillan, pp. 203-222.

Fair Admissions Campaign (2014) Catholic schools and the Income Deprivation Affecting Children Index. Available from http://fairadmissions.org.uk/catholic-schools-and-the-income-deprivation-affecting-children-index/ (accessed 20 September 2018).

Fried C (1976) Right and Wrong. Cambridge, MA: Harvard University Press.

Galston W (2002) Liberal Pluralism: The Implications of Value Pluralism for Political Theory and Practice. Cambridge: Cambridge University Press.

Gardner P (2014) Hand's academy challenge: some starter questions. Journal of Philosophy of Education 48 (4), $637-645$.

Gibbons S and Silva O (2011) Faith primary schools: better schools or better pupils? Journal of Labor Economics 29 (3), 589-635.

Gorard S (2006) Is there a school mix effect? Educational Review 58 (1), 87-94.

Groothuis D (2004) On not abolishing faith schools: a response to Michael Hand and Harvey Siegel. Theory and Research in Education 2 (2), 177-188.

Gutmann A (1996) Challenges of multiculturalism in democratic education. In Fullinwider RK (ed.), Public Education in a Multi-Cultural Society: Policy, Theory, Critique. New York: Cambridge University Press, pp. 156-179.

Hand M (2003) A philosophical objection to faith schools. Theory and Research in Education 1 (1), 89-99.

Hand M (2004) The problem with faith schools: a reply to my critics. Theory and Research in Education 2 (3), 343-353.

Hand M (2012) A new dawn for faith-based education? Opportunities for religious organisations in the UK's new school system. Journal of Philosophy of Education 46 (4), 546-559.

Harker R and Tymms P (2004) The effect of student composition on school outcomes. School Effectiveness and School Improvement 15 (2), 177-199.

Hewstone $\mathbf{M}$ et al. (2018) Influence of segregation versus mixing: intergroup contact and attitudes among White-British and Asian-British students in high schools in Oldham, England. Theory and Research in Education 16 (2), 179-203.

HMSO (2001) Community Cohesion: A Report of the Independent Review Team Chaired by Ted Cantle. London: HMSO.

Hughes J et al. (2013) Inter-group contact at school and social attitudes: evidence from Northern Ireland. Oxford Review of Education 39 (6), 761-779.

Kagan S (1989) The Limits of Morality. Oxford: Oxford University Press.

Kymlicka W (2001) Education for Citizenship. In Kymlicka W (ed.), Politics in the Vernacular. Oxford: Oxford University Press, pp. 293-316.

MacMullen I (2007) Faith in Schools? Princeton, NJ: Princeton University Press. 
Marshall G, Swift A and Roberts S (1997) Against the Odds? Social Class and Social Justice in Industrial Societies. Oxford: Oxford University Press.

Mason A (2010) Integration, cohesion and national identity: theoretical reflections on recent British policy. British Journal of Political Science 40 (4), 857-874.

May T (2016) Britain, the great meritocracy: prime minister's speech. Available from https:/www.gov.uk/government/ speeches/britain-the-great-meritocracy-prime-ministers-speech (accessed 20 September 2018).

McLaughlin T (2008) The Ethics of Separate Schools. In Carr D, Halstead M and Pring R (eds), Liberalism, Education \& Schooling: Essays by T.H McLaughlin. Exeter: Imprint Academic, pp. 175-198.

Mulligan J (1999) Catholic Education: The Future is Now. Toronto: Novalis.

Mullin A (2014) Children, paternalism and the development of autonomy. Ethical Theory and Moral Practice 17 (3), $413-426$.

Musset P (2012) School Choice and Equity. OECD Education Working Papers No. 66. Available from http://www.oecd-ilibrary.org/ education/school-choice-and-equity_5k9fq23507vc-en (accessed 20 September 2018).

Pettinger P (2014) Social selection and religiously selective faith schools. Forum 56 (3), 473-484.

Pring R (2018) The Future of Publicly Funded Faith Schools. Abingdon: Routledge.

Shorten A (2017) Discrimination and Admissions in Denominational, Faith and Parochial Schools. Paper prepared for ECPR Joint Sessions, Nottingham, UK, April 2017.

Siegel H (2004) Faith, knowledge and indoctrination: a friendly response to hand. Theory and Research in Education 2 (1), $75-83$.

Sullivan A et al. (2018) Educational attainment in the short and long term: was there an advantage to attending faith, private and selective schools for pupils in the 1980s? Oxford Review of Education 44 (6), 806-822.

Tadros V (2015) Wrongful intentions without closeness. Philosophy and Public Affairs 43 (1), 52-74.

Taylor R (2015) Responsibility for the soul of the child: the role of the state and parents in determining religious upbringing and education. International Journal of Law, Policy and the Family 29 (1), 15-35

Thiessen EJ (1993) Teaching for Commitment: Liberal Education, Indoctrination and Christian Nurture. Montreal: McGill-Queen's University Press.

Thrupp M, Lauder H and Robinson T (2002) School composition and peer effects. International Journal of Educational Research 37, 483-504.

Vatican Council II (1965) Declaration on Christian Education (Gravissimum Educationis). Available from http://www.vatican.va/ archive/hist_councils/ii_vatican_council/documents/vat-ii_decl_19651028_gravissimum-educationis_en.html (accessed 20 September 2018).

YouGov/University of Lancaster (2013) Faith Matters Results 130618 Faith Schools. Available from https:/d25d2506sfb94s.cloudfront.net/cumulus_uploads/document/4n6d3tnayp/YG-Archive-University-of-Lancaster-Faith-Matters-Debate-results-180613faith-schools.pdf (accessed 20 September 2018).

Cite this article: Clayton M, Mason A, Swift A, Wareham R (2021). The Political Morality of School Composition: The Case of Religious Selection. British Journal of Political Science 51, 827-844. https://doi.org/10.1017/S0007123418000649 